\title{
EFFECT OF SOME ENGINEERING FACTORS ON THE PROPERTIES OF THE BIOFERT
}

\author{
Ramy Hamouda ${ }^{*}$, Adel Bahnasawy**, Samir Ali**, \\ Zakaria El-Haddad** and El-Shahat Ramadan***
}

\begin{abstract}
An experiment was conducted successively to study the effect of fermentation conditions on the properties of biofertilizer from cow manure. Fermentation temperatures $\left(30,35\right.$, and $\left.50^{\circ} \mathrm{C}\right)$, aeration rates (1, 2, and $5 \mathrm{~L} / \mathrm{min})$ and agitation rotation speeds (200, 300, and $500 \mathrm{rpm})$ were the most important factors affecting the biofert properties. Moisture content, bulk density, total solid, electrical conductivity, Hydrogen ion concentration, total nitrogen, organic matter, phosphorus, potassium and microbial changes properties were determined. The results indicated that the lowest value of bulk density was $946.63 \mathrm{~kg} / \mathrm{m}^{3}$ at temperature of $50^{\circ} \mathrm{C}, 300 \mathrm{rpm}$ agitation speed and 5 liter/ min, ventilation rate while the highest value $\left(983.17 \mathrm{~kg} / \mathrm{m}^{3}\right)$ obtained at temperature $30^{\circ} \mathrm{C}, 500 \mathrm{rpm}$ agitation speed and 1 liter/ min ventilation rate. The lowest moisture content was $79.87 \%$ at temperature of $30^{\circ} \mathrm{C}$, agitation speed of $200 \mathrm{rpm}$ and ventilation rate of 1 liter/min while the highest value was $83.19 \%$ at temperature of $50^{\circ} \mathrm{C}$, agitation of 500rpm and ventilation rate of 5 liter/ min. The electrical conductivity increased from $11.6 \mathrm{ds} \mathrm{m-1} \mathrm{at} \mathrm{the} \mathrm{start} \mathrm{of}$ fermentation to $35.07 \mathrm{ds} \mathrm{m}-1$ at the end of fermentation period depending on the treatments under study. The $\mathrm{pH}$ decreased from 8.13 at the start of fermentation to 6.77 at the end of fermentation period. The total solid of the biofert decreased from $21.2 \%$ at the start of fermentation to $16.81 \%$ at the end of fermentation period, where the lowest value was $16.81 \%$ at temperature of $50^{\circ} \mathrm{C}$, agitation speed of 500rpm and ventilation rate of 5 liter/min and the highest value (20.13\%) recorded at temperature of $30^{\circ} \mathrm{C}$, agitation speed of 200rpm and ventilation rate of 1 liter/ min.
\end{abstract}

Keywords: dairy manure, Biofert, fermentation, agitation, pathogenic, ventilation.

\footnotetext{
* Graduate Student of Agric. Eng. Dep., Fac. of Agric., Benha Univ., Egypt **Prof. of Agric. Eng., Fac. of Agric., Benha Univ., Egypt

*** Prof. of Microbiology, Fac. of Agric., Ain Shams Univ., Egypt
} 
The lowest $T N \%$ was $0.41 \%$ at $50^{\circ} \mathrm{C}$ fermentation temperature, agitation speed of 500rpm and ventilation rate of 1 liter/min while, the highest value $(1.18 \%)$ obtained at temperature of $35^{\circ} \mathrm{C}$, agitation speed of $300 \mathrm{rpm}$ and ventilation rate of 5 liter/ min. The O.M \% decreased from $34.2 \%$ at the start of fermentation to $10.97 \%$ at the end of fermentation period. The lowest value of O.M\% was $10.97 \%$ at temperature of $50^{\circ} \mathrm{C}$, agitation speed of 500rpm and ventilation rate of 5 liter/ min while the highest value was $16.63 \%$ at temperature of $30^{\circ} \mathrm{C}$, agitation speed of 200 rpm and ventilation rate of 1 liter/ min. The total phosphorus and potassium increased by increasing the fermentation temperature from 120 to $322 \mathrm{ppm}$, and from 150 to $334.33 \mathrm{ppm}$, respectively by the end of fermentation period. Regarding the microbial changes, all treatments showed disappearance of pathogenic microorganisms at temperature of $50^{\circ} \mathrm{C}$, at all agitation speeds and ventilation rates.

\section{INTRODUCTION}

nimal slurry is widely used as a fertilizer in organic farms.
Dairy cattle typically produce between $42 \mathrm{~kg}$ and $64 \mathrm{~kg}$
(depending on body weight) of manure per day, so if they are housed for 50\% of the year that corresponds to 7.6-11.6 tonnes per cow. In many developing nations, animal faeces have been composted and used to fertilize farm fields (Ogbeide and Aisien, 2000; Audu et al., 2003). Many factors, including the type and concentration of substrate, temperature, moisture, $\mathrm{pH}$, etc., may affect the performance of the anaerobic digestion process in the bioreactor (Behera et al., 2010; Jeong et al., 2010). The anaerobic digestion of organic waste is also an environmentally useful technology. Ward et al. (2008) described the benefits of this process to reduce environmental pollution in two main ways: the sealed environment of the process prevents exit of methane into the atmosphere, while burning of the methane will release carbonneutral carbon dioxide (no net effect on atmospheric carbon dioxide and other greenhouse gases). On the other hand, the anaerobic process has some disadvantages such as long retention times and low removal efficiencies of organic compounds (Park et al., 2005). Consequently, various physical, chemical and enzymatic pre-treatments are required to 
increase substrate solubility and accelerate the biodegradation rate of solid organic waste (Torres and Llorens, 2008; Charles et al., 2009In the described manner of treating the liquid manure its temperature is augmented; our findings show that in the summer time that it is possible to supply the air from outside the barn to the aerator pump whereas in winter it is recommendable to supply warmed air from the barn interior. In this way the liquid manure heating is accelerated and at the same time the barn microclimate, from which the bad smell is removed, is improved. If during aeration the temperature of the liquid manure rises to 25-30 ${ }^{\circ} \mathrm{C}$, germination of the weed plant seeds, coming from the ingredients of the feed meal through the animals' digestive tract into the liquid manure, is reduced and a considerable number of parasites and disease-causers are destroyed. It has been found out that the fly larvae and the rodents, which are regular companions in the liquid manure storages; do not have optimal conditions for the procreation after a short time of the liquid manure aeration and homogenization.

The main objective of this work was to study the possibility of using dairy manure in Biofert production to eliminate the pollution effect and contribute in agricultural biofertilizer sacristy problem. To achieve this goal, the fermentation temperature, and agitation speed and ventilation rate as the most important factors affecting the physical, chemical and microbiological properties the Biofert were studied.

\section{MATERIALS AND METHODS}

\section{Materials used:-}

\section{Dairy manure}

This waste was obtained from animal farms at Sekem, Sharkia Governorate, Egypt. The main components of this waste was: Total nitrogen (TN) of $1.42 \%$; Phosphorus (P), of $0.012 \%$; Potassium (K), of $0.015 \%$; Organic Matter $(\mathrm{OM})$, of $34.2 \%$ and $\mathrm{C} / \mathrm{N}$, of 13.97 ; Moisture, of $78.8 \% \mathrm{pH}$, of 8.13 and Electrical Conductivity (EC), $11.6 \mathrm{dSm}^{-1}(9280$ ppm).

\section{Measurements and Instrumentation:}

Scanning thermometer was used to measure temperature (model, DigiSense 69202-30 measuring range from-250 to1800 ${ }^{\circ} \mathrm{C}+/-0.1 \%$,USA). Dissolved oxygen was measured by a dissolved oxygen meter (model, 
HI9143 measuring range from 0.01 to $300 \% \mathrm{O} 2+/-1.5 \%$ full scale $\%$ $\mathrm{O} 2$, Italy). The $\mathrm{pH}$ was measured by the $\mathrm{pH}$ meter (model, ORION230A measuring range from 2 to $19.999+/-0.005$, USA). Electrical conductivity was measured by EC meter, ICM model ORION 105 measuring range from 0 to 199.990 0.1, USA). Ammonia (NH3) as nitrite (NO2) and nitrate (NO3) was measured by kjeldahl digestion (model, Vapodest measuring range from $0.1 \mathrm{mgN}$ to $200 \mathrm{gN}+/-1.5 \%$ full scale $\%$ N,Germany). The total phosphorus was measured by the spectrophotometer (model, $6320 \mathrm{D}$ measuring range from 0.1 to 1000 Concentration $+/-1 \mathrm{~nm} \lambda, \mathrm{UK})$. The total potassium was measured by the flame photometer (model, Jenway PFP7 measuring range from 0 to 10 $+/-0.2 \mathrm{ppm}, \mathrm{USA}$ ). Voltage (volt) and current (ampere) were measure by the Avometer (model, DT266 clamp meter measuring range from 200 to 1000A, China).

BioFlo 110 fermentor:A $20 \mathrm{~L}$ batch fermentor was used for the production of biofert from dairy manure. The experimental set-up (fig.1) consisted of the fermenter, the air supply and the computer based data acquisition and control system. The fermenter and all accessories were chemically sterilized using $2 \%$ potassium metabisulfite solution and then washed with hot water several times before starting the experiment in order to remove any chemical traces. The reactor was then filled with 20 $\mathrm{L}$ of dairy manure. the reactor was operated at air flow rate 1,2 and $5 \mathrm{~L} / \mathrm{min}$ and mixing speed of 200, 300 and $500 \mathrm{rpm}$. The dissolved oxygen and temperature of the reactor were monitored continuously.

The experiment was devoted to study physical, chemical and microbiological properties of nutrient solution (Biofert) as affected by temperature with $\left(30,35\right.$, and $\left.50^{\circ} \mathrm{C}\right)$, aeration rate $(1,2$, and $5 \mathrm{~L} / \mathrm{min})$ and agitation rotation speed $(200,300$, and $500 \mathrm{rpm})$. A total of 81 runs including 3 replicates were conducted.

\section{Biofert analysis:}

\section{Physical and chemical analysis:}

Bulk density was calculated as a ratio between dry weights of the sample (g) to its volume $\left(\mathrm{cm}^{3}\right)$, according to (Clark et al., 1998). Electrical 
conductivity measurements were run in 1:1 Biofert water extracts according to (Richards, 1954), using EC meter, ICM model 71150.

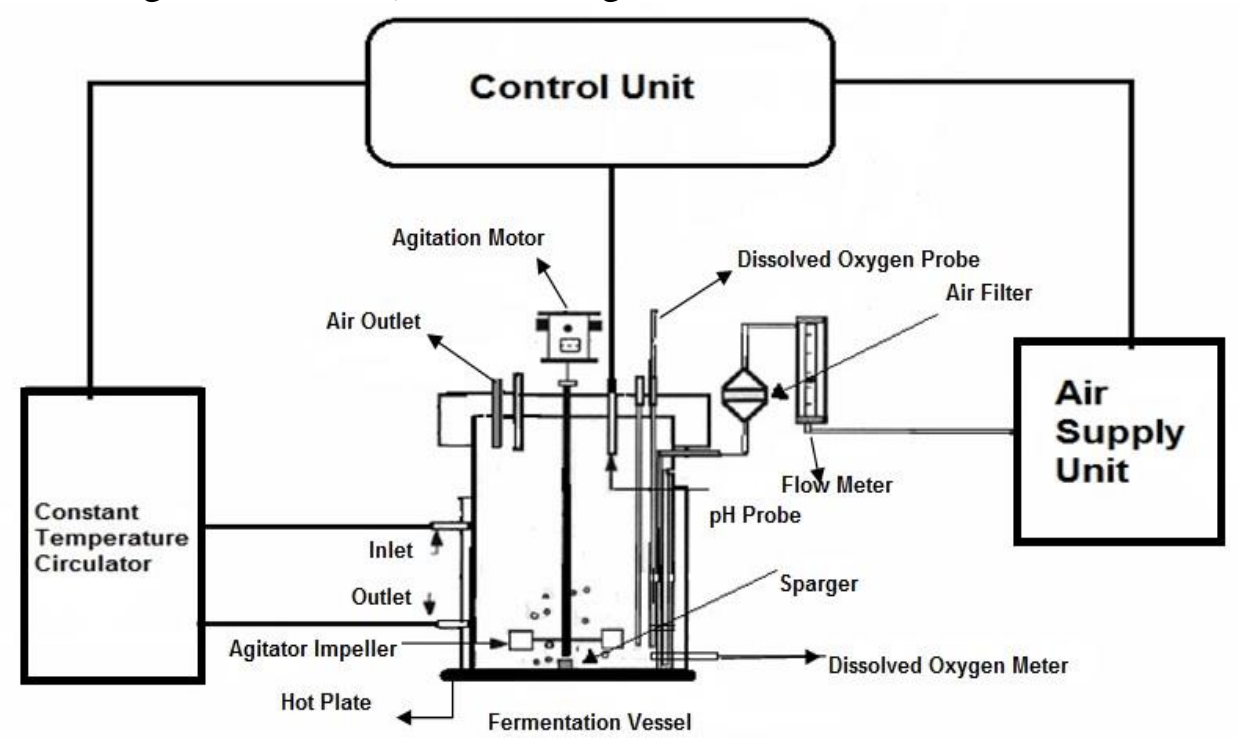

Figure (1): the experimental-setup

Total nitrogen was determined Kjeldahl digestion method as described by Jackson (1973). Soluble nitrogen forms were determined according to the method described by Page et al. (1982). Total phosphorus was determined using spectrophotometer method (Olsen et al., 1954). Total potassium was determined using flame photometric method (Chapman and Pratt, 1961). Microbiological analysis was performed according to Brinton (1995).

\section{RESULTS AND DISCUSSION}

This study was carried out to investigate the properties of the biofert that produced under different condition of fermentation temperatures, agitation speeds, and ventilation rates. Physical, chemical and microbiological properties were studied. These properties are: moisture content, bulk density, total solid, electrical conductivity, hydrogen ion concentration, total nitrogen, organic matter, phosphorus, potassium, and microbial changes.

\section{Physical properties:-}

\section{Biofert Bulk Density:}

Figure (2) shows the bulk density (BD) of the biofert as affected by the fermentation temperature, agitation speed and ventilation rate. The results 
indicated that the $\mathrm{BD}$ decreased with increasing the ventilation rate at different agitation speeds and fermentation temperature, where, it decreased from 970.60 to $951.04 \mathrm{~kg} / \mathrm{m}^{3}$. On the other hands, the BD increased with increasing the agitation speed, where, it increased from 966.41 to $970.28 \mathrm{~kg} / \mathrm{m}^{3}$ with changing the agitation speed from 200 to 500 rpm at $30^{\circ} \mathrm{C}$, from 967.19 to $962.83 \mathrm{~kg} / \mathrm{m}^{3}$ at $35^{\circ} \mathrm{C}$, and from 946.32 to $953.66 \mathrm{~kg} / \mathrm{m}^{3}$ at $50^{\circ} \mathrm{C}$. Regarding the effect of the fermentation temperature, it could be seen that, the BD of the biofert where they were 967.80, 967.59, 955.95 at fermentation temperature 30,35 , and $50^{\circ} \mathrm{C}$, respectively. The $\mathrm{BD}$ decreased with increasing the ventilation rate, where, it decreased from 970.60 to $951.04 \mathrm{~kg} / \mathrm{m}^{3}$. Multiple Regressions analysis was carried out to find a relation between fermentation temperature, agitation speed, ventilation rate and the biofert Bulk density, the best form obtained was as follows:

$$
B D=993.99-0.75 T+0.02 A-3.11 V \quad \mathrm{R}^{2}=0.82
$$

Where:-

$\mathrm{BD}$ is the bulk density, $\mathrm{kg} / \mathrm{m}^{3}$

$\mathrm{T}$ is the fermentation temperature, ${ }^{\circ} \mathrm{C}$

A is the agitation speed, rpm

$\mathrm{V}$ is the ventilation rate, $\mathrm{L} / \mathrm{min}$

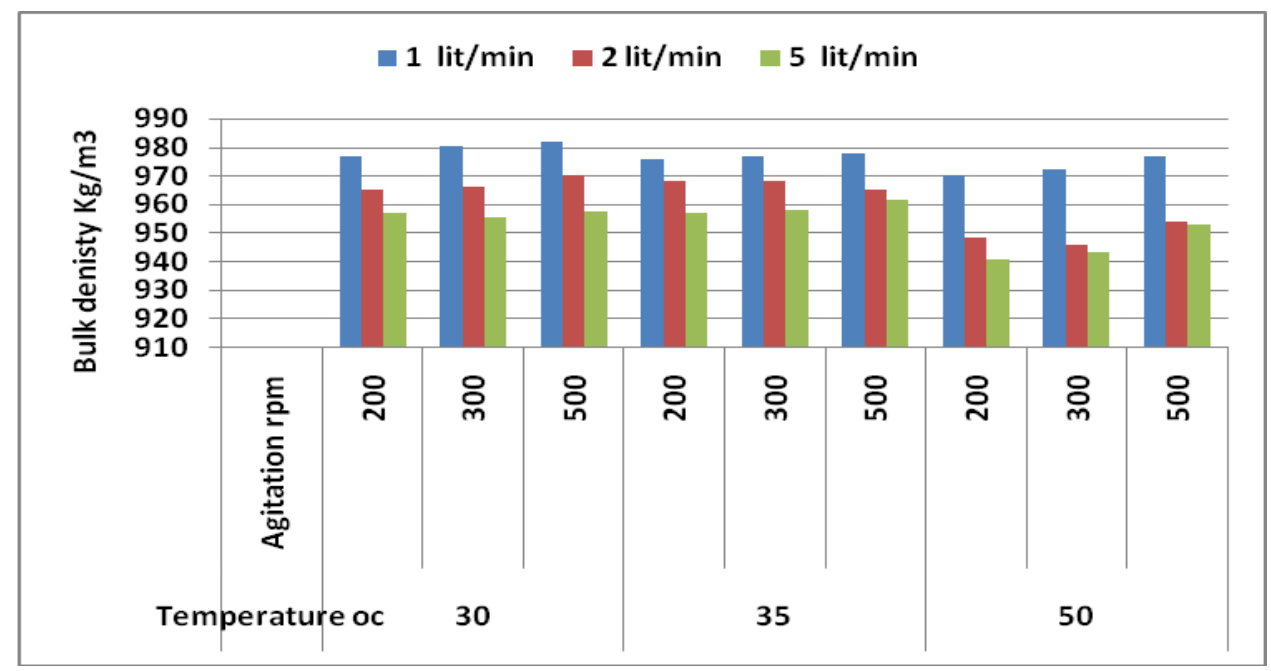

Figure (2): The effect of fermentation temperature, agitation speed and ventilation rate on bulk density of Biofert. 


\section{Biofert moisture content:}

Figure (3) shows the effect of fermentation temperature, $\mathrm{T}(30,35$, and $\left.50^{\circ} \mathrm{C}\right)$, agitation speed, $\mathrm{A}(200,300$, and $500 \mathrm{rpm})$ and ventilation rate, $\mathrm{V}$ $(1,2$, and $5 \mathrm{~L} / \mathrm{min}$ ), on the moisture content (MC) of the resultant biofert. It could be seen that the lowest moisture content (79.87\%) was obtained at $30^{\circ} \mathrm{C}$ fermentation temperature, $1 \mathrm{~L} / \mathrm{min}$ ventilation rate and $200 \mathrm{rpm}$ agitation speed, meanwhile, the highest $\mathrm{MC}$ of the biofert $(83.11 \%)$ was recorded at $5 \mathrm{~L} / \mathrm{min}$ ventilation rate and $500 \mathrm{rpm}$ agitation speed. At $35^{\circ} \mathrm{C}$ fermentation temperature, the lowest moisture content $(80.12 \%)$ of Biofert recorded at $1 \mathrm{~L} / \mathrm{min}$ ventilation rate and $200 \mathrm{rpm}$ agitation speed, meanwhile, the highest $\mathrm{MC}$ of the Biofert $(83.01 \%)$ was recorded at 5 $\mathrm{L} / \mathrm{min}$ ventilation rate and $500 \mathrm{rpm}$ agitation speed. At $50^{\circ} \mathrm{C}$ fermentation temperature, the lowest moisture content $(80.18 \%)$ of Biofert recorded at $1 \mathrm{~L} / \mathrm{min}$ ventilation rate and $200 \mathrm{rpm}$ agitation speed, meanwhile, the highest MC of the Biofert (83.19\%) was recorded at $5 \mathrm{~L} / \mathrm{min}$ ventilation rate and $500 \mathrm{rpm}$ agitation speed.

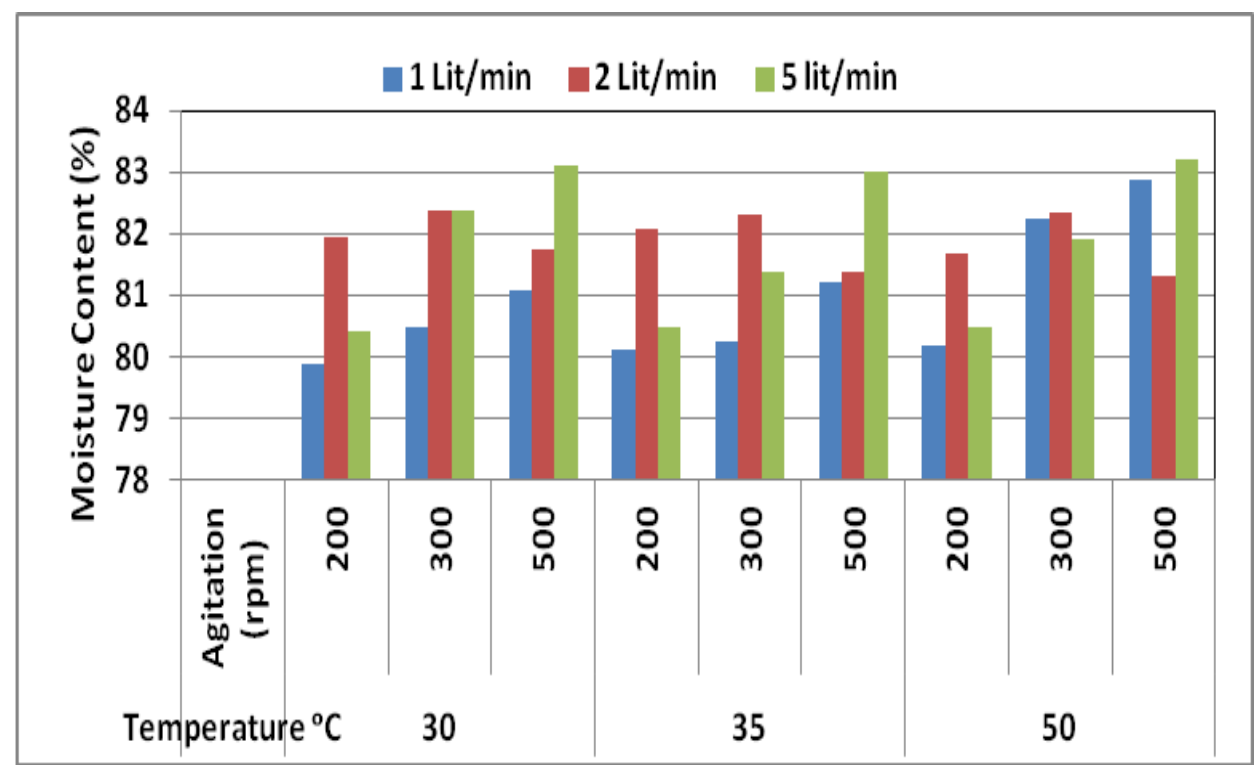

Figure (3): The effect of fermentation temperature, agitation speed and ventilation rate on the moisture content of the Biofert. 


\section{Biofert total solid \%.}

Figure (4) shows the effect of fermentation temperature (T), agitation speed (A) and ventilation rate (V) on the total solid (TSS) of the biofert. The results showed that the TSS varied slightly from 18.20 to $18.64 \%$ as fermentation temperature changed from $30-50^{\circ} \mathrm{C}$. TSS varied from 17.55 to $19.26 \%$ as the agitation speed changed from 200 to $500 \mathrm{rpm}$. On the other hand, TSS ranged from 18.10 to $19.08 \%$ as the ventilation rate changed from $1 \mathrm{~L} / \mathrm{min}$ to $5 \mathrm{~L} / \mathrm{min}$.

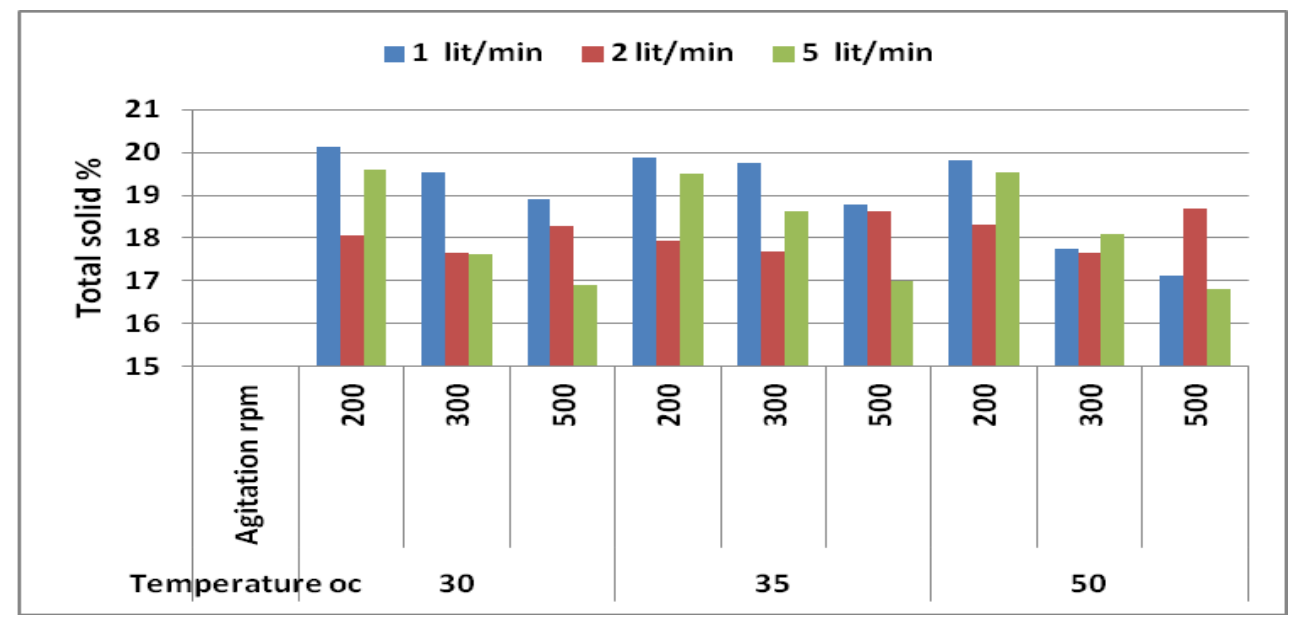

Figure (4): The effect of fermentation temperature, agitation speed and ventilation rate on the total solid of Biofert

\section{Chemical properties:-}

\section{Biofert electrical conductivity (EC).}

Figure (5) shows the effect of fermentation temperature (T), agitation speed (A) and ventilation rate (V) on the EC of the biofert. It could be seen that the biofert EC increased with increasing all treatments under study (T, A and V). The average EC increased from 29.54 to $33.97 \mathrm{ds} / \mathrm{m}$. as the fermentation temperature from 30 to $50^{\circ} \mathrm{C}$, on the other hand, the EC increased from 28.33 to $30.96 \mathrm{ds} / \mathrm{m}$ as the agitation speed increased from 200 to $500 \mathrm{rpm}$ at $30^{\circ} \mathrm{C}, 31.91$ to $33.60 \mathrm{ds} / \mathrm{m}$ at $35^{\circ} \mathrm{C}$ and from 33.11 to $34.61 \mathrm{ds} / \mathrm{m}$ at $50^{\circ} \mathrm{C}$ for the same previous range of the agitation speed (200 to $500 \mathrm{rpm}$ ). These results could be attributed to with increasing these factors ( $\mathrm{T}, \mathrm{A}$ and $\mathrm{V}$ ) caused increasing in the water evaporation while result in increasing of the salinity of the biofert solution. It means that the 
mineralization process of organic wastes increased gradually which led to release cations and anions showing the highest peak at the end of fermentation Raviv et al., 1986). The best fit for the relationship between the electrical conductivity, temperature, agitation speed and ventilation rat was as follows:

$$
E C=21.02+0.19 T+0.006 A+0.64 V \quad \mathrm{R}^{2}=0.75
$$

Where:-

EC is the electrical conductivity dsm-1 $(\mathrm{ds} / \mathrm{m}=800 \mathrm{ppm})$

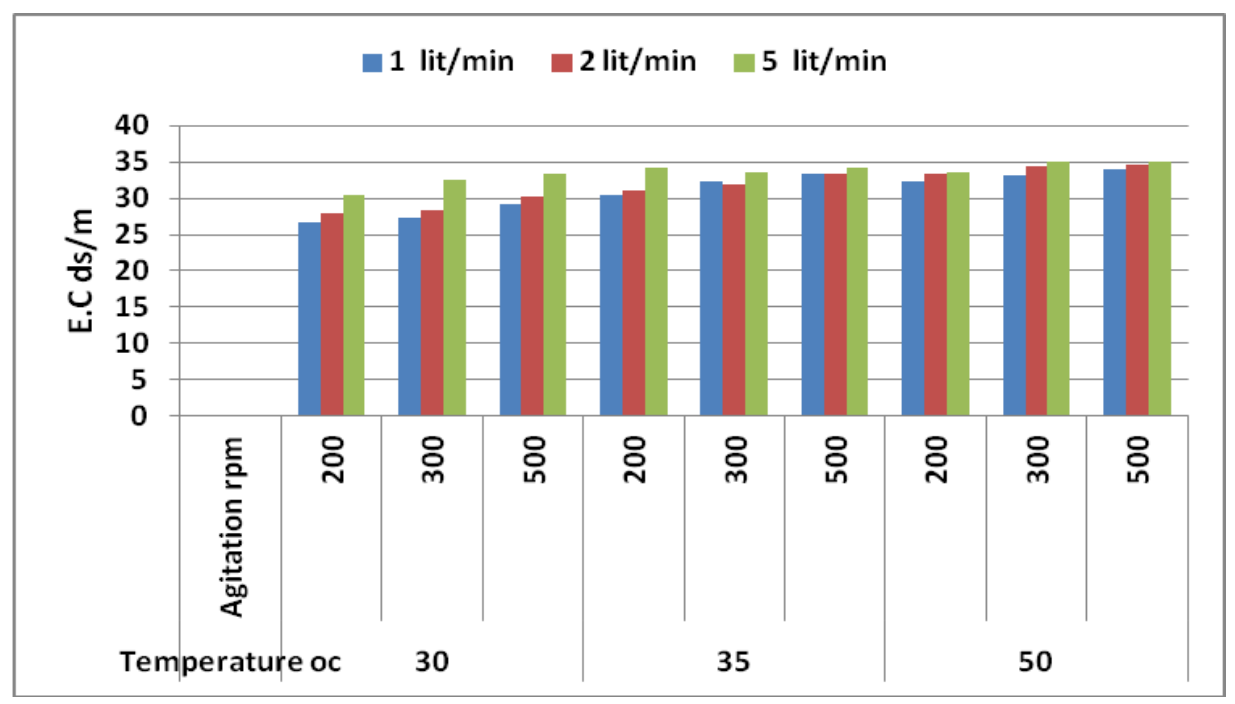

Figure (5): The effect of fermentation temperature, agitation speed and Ventilation rate on the electrical conductivity of Biofert

\section{Biofert Hydrogen ion concentration (pH).}

Figure (6) shows the effect of fermentation temperature (T), agitation speed (A) and ventilation rate $(\mathrm{V})$ on the $\mathrm{pH}$ of the biofert. The results indicate that the $\mathrm{pH}$ ranged from 4.79 to 5.48 as the fermentation temperature changed from 30 to $50^{\circ} \mathrm{C}$ and from 4.61 to 5.79 , as the agitation speed changed from 200 to $500 \mathrm{rpm}$. The $\mathrm{pH}$ ranged from 4.95 to 5.29 as the ventilation rate varied from $1 \mathrm{~L} / \mathrm{min}$ to $5 \mathrm{~L} / \mathrm{min}$. 


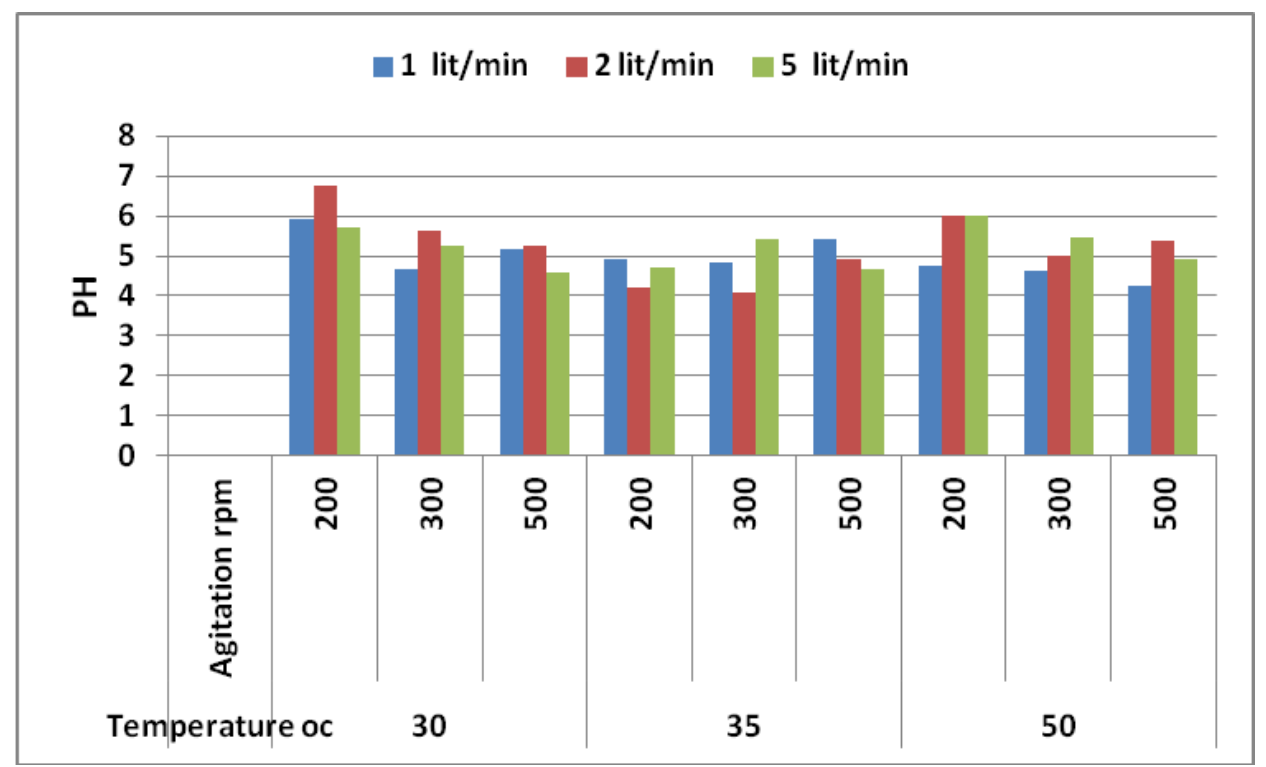

Figure (6): The effect of fermentation temperature, agitation speed and Ventilation rate on $\mathrm{pH}$ of Biofert.

\section{Changes in Biofert total nitrogen (TN) \%.}

Figure (7) shows the effect of the fermentation temperature, agitation speed and ventilation rate on the $\mathrm{TN} \%$ of the biofert. It could be seen that the TN\% increased slightly with the agitation speed, where, it ranged from 0.61 to $1.06 \%$ as the agitation speed changed from 200 to $500 \mathrm{rpm}$ .On the other hand, TN was affected by the ventilation rate, where it increased from 0.68 to $1.00 \%$ as ventilation rate increased from 1 to 5 $\mathrm{L} / \mathrm{min}$. TN\% ranged from 0.63 to $1.04 \%$ as the fermentation temperature ranged from $30-50^{\circ} \mathrm{C}$. The best fit for the relationship between the total nitrogen, Temperature, agitation and ventilation rat was as fallowed equation:

$$
T N=1.30-0.017 T+4.87 A+0.072 V \quad \mathrm{R}^{2}=0.72
$$

Where:-

TN is total nitrogen (TN), \%. 


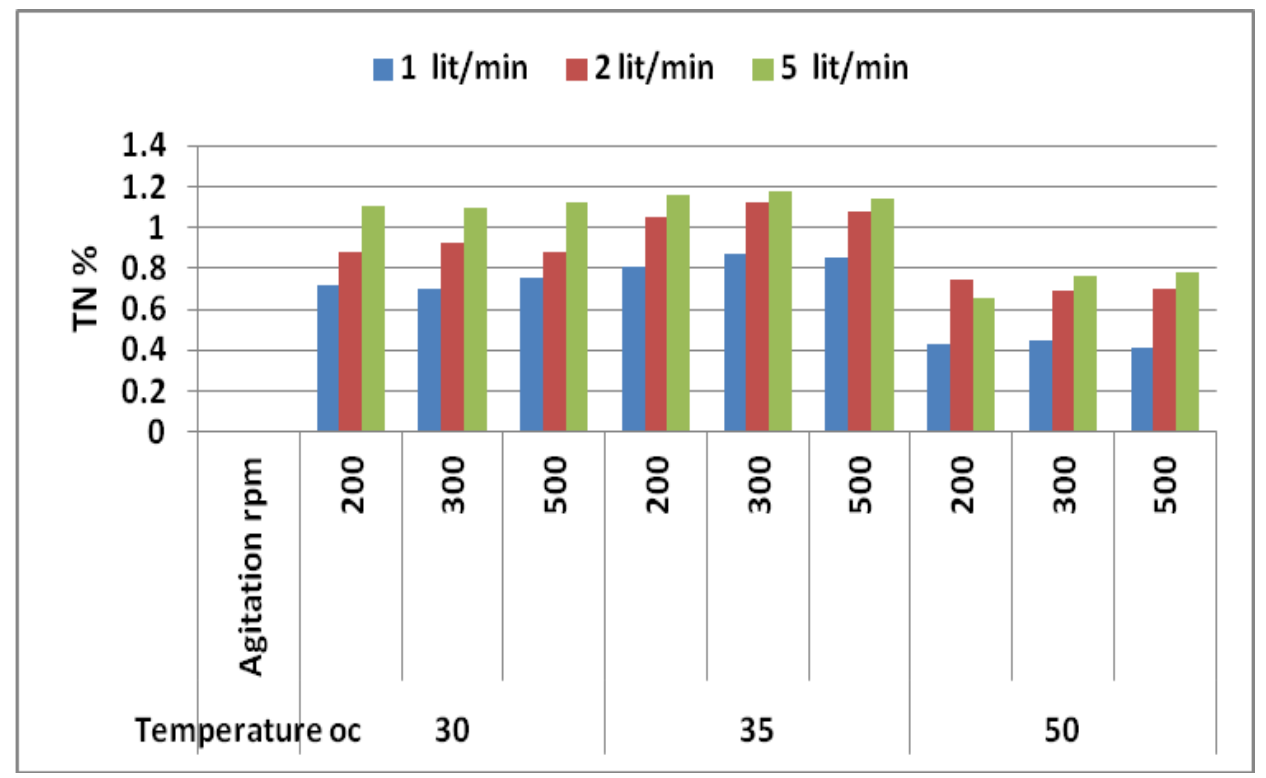

Figure (7): The effect of fermentation temperature, agitation speed and Ventilation rate on total nitrogen (TN) \% Biofert

\section{Changes in Biofert Organic matter (O.M) \% .}

Figure (8) shows the effect of O.M \% of the biofert as affected by the fermentation temperature, agitation speed and ventilation rate. It could be seen that the O.M \% ranged from 11.53 - $16.07 \%$ depending on the agitation speed. On the other hand, the OM changed slightly as the ventilation rate varied, where it changed from 13.57 to $13.84 \%$ where the VR varied from 1 to $5 \mathrm{~L} / \mathrm{min}$. Regarding the effect of fermentation temperature, it was found that the OM decreased from 15.01 to $12.64 \%$ as the fermentation temperature increased from 30 to $50^{\circ} \mathrm{C}$. Regression analysis was carried out to find a relationship between the organic matter, temperature, agitation and ventilation rat, and the most appropriate form is shown as follows:

$$
O M=18.47-0.06 T-0.007 A+0.29 V \quad \mathrm{R}^{2}=0.77
$$

Where:-

$\mathrm{OM}$ is organic matter (O.M), \%. 


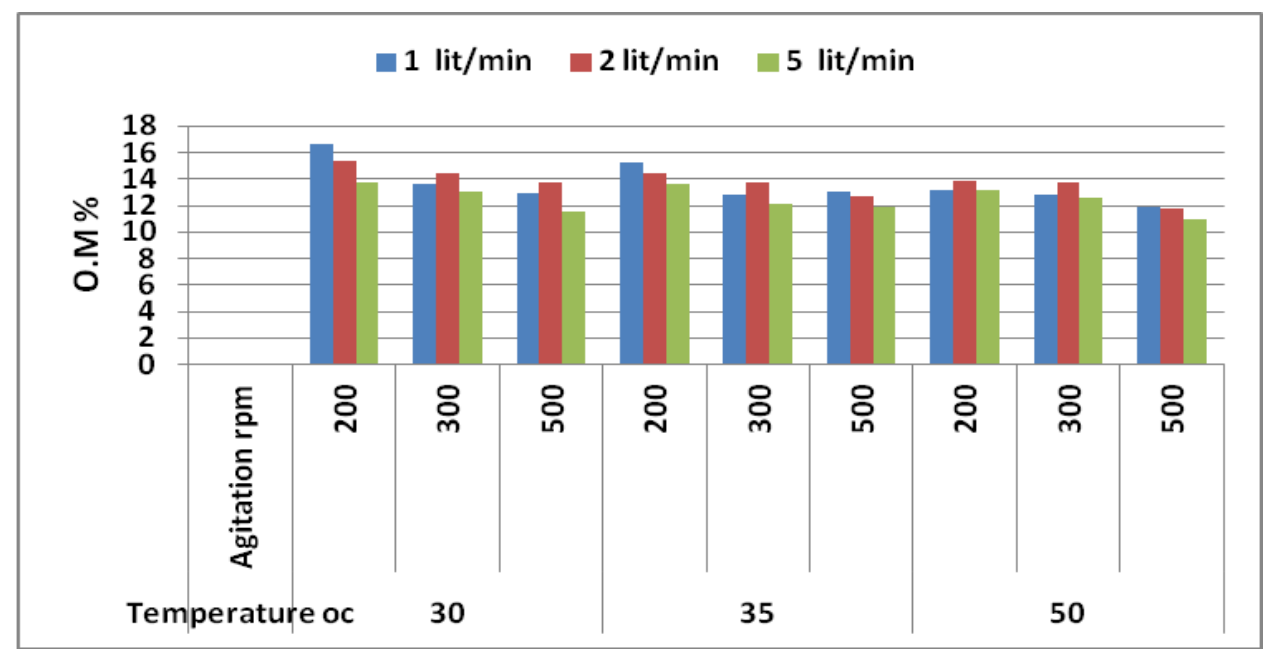

Figure (8): The effect of fermentation temperature, agitation speed and Ventilation rate on organic matter (O.M) \% Biofert.

\section{Changes in Biofert Phosphorus.}

Figure (9) shows the effect of fermentation temperature, agitation speed and ventilation rate on the total phosphorus content of the biofert. It seems that the T.P increased by increasing the fermentation temperature, agitation speed and ventilation rate under study, where it increased from 145.59 to $275.70 \mathrm{ppm}$ as the ventilation rate increased from $1 \mathrm{~L} / \mathrm{min}$ to 5 $\mathrm{L} / \mathrm{min}$, on the other hand, it increased from 163.44 to $223.33 \mathrm{ppm}$ with increasing the agitation speed from $200-500 \mathrm{rpm}$. The T.P increased from 173.81 to $216.96 \mathrm{ppm}$ with increasing the fermentation temperature from $30-50^{\circ} \mathrm{C}$.It could be conducted that the effect of ventilation rate on the T.P was higher than the effect of both agitation speed and fermentation temperature. But agitation speed effect was higher than the effect of fermentation temperature. The decreases of phosphorus concentration in the first stage of composting could be due to the microbial immobilization of available phosphorus (Jackson, 1973), while the increase of phosphorus during the further stages of composting (mesophilic) could be due to either the microbial mineralization of organic phosphorus or the chelation of unavailable phosphorus with the organic acids, that found during the microbial decomposition of organic wastes. These data are in agreement with those of Elvira et al., (1998), 
Singh and Sharma (2002). The best fit for the relationship between the total phosphorus, Temperature, agitation and ventilation rat was as fallowed equation:

$$
T P=15.88+2.03 T+0.03 A+33.75 V \quad \mathrm{R}^{2}=0.94
$$

Where:-

TP is Total phosphorus, ppm

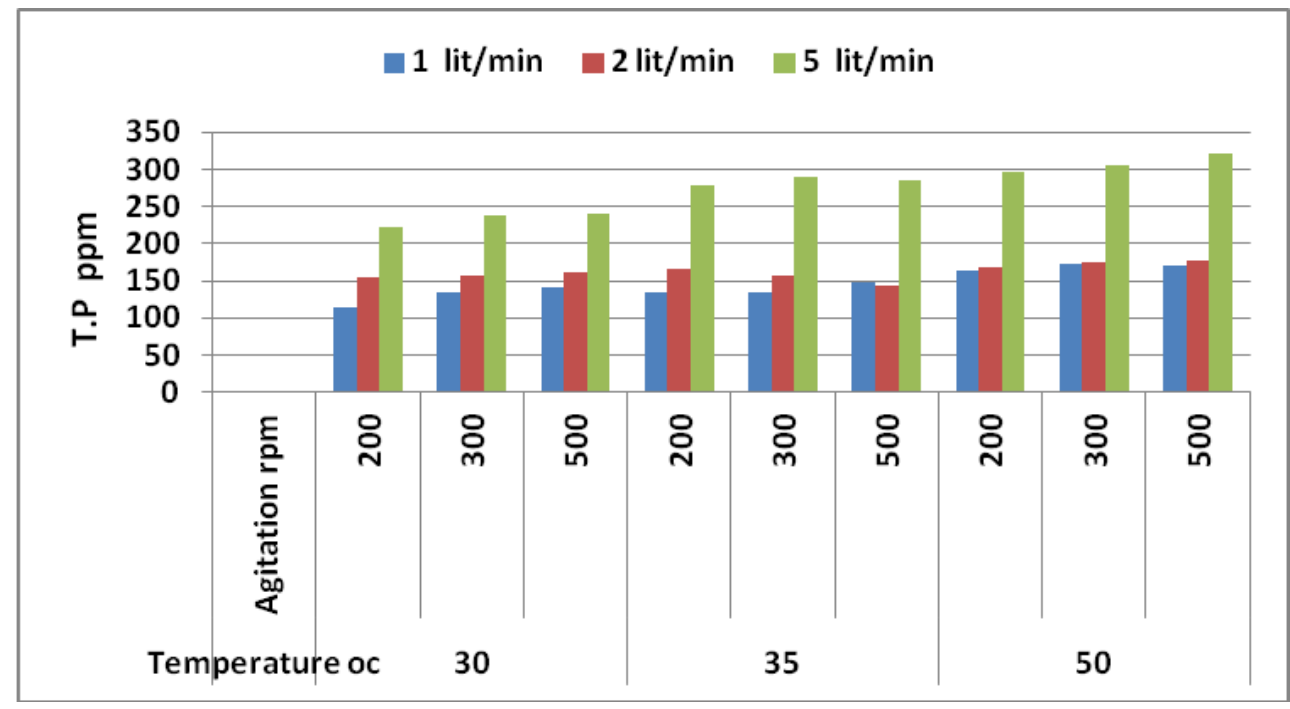

Figure (9): The effect of fermentation temperature, agitation speed and ventilation rate on the total phosphorus Biofert.

\section{Changes in Biofert potassium.}

Figure (10) shows the effect of fermentation temperature, agitation speed and ventilation rate on the total potassium (T.K) content of the biofert. It could be seems that the T.K increased from 244.63 to $295.30 \mathrm{ppm}$ as the ventilation rate varied from 1 to $5 \mathrm{~L} / \mathrm{min}$. It increased from 274.89 to $286.44 \mathrm{ppm}, 268.89$ to $289.11 \mathrm{ppm}$, and 238.11 to $245.00 \mathrm{ppm}$ at 30,35 and $50^{\circ} \mathrm{C}$, respectively as the agitation speed increased from $200-500$ rpm. Concerning the effect of fermentation temperature, it was found that the T.K decreased from 280.74 to241.19 $\mathrm{ppm}$ as the temperature increased from 30 to $50^{\circ} \mathrm{C}$. These data are in harmony with those of Singh and Sharma (2002) who found that the significant increase in 
potassium concentration by the end fermentation period could be due to the mineralization of organic matter. The best fit for the relationship between the total phosphorus, Temperature, agitation and ventilation rat was as fallowed equation:

$$
T k=275.07-1.33 T+0.015 A+15.785 V \quad \mathrm{R}^{2}=0.89
$$

Where:-

Tk is Total potassium, ppm.

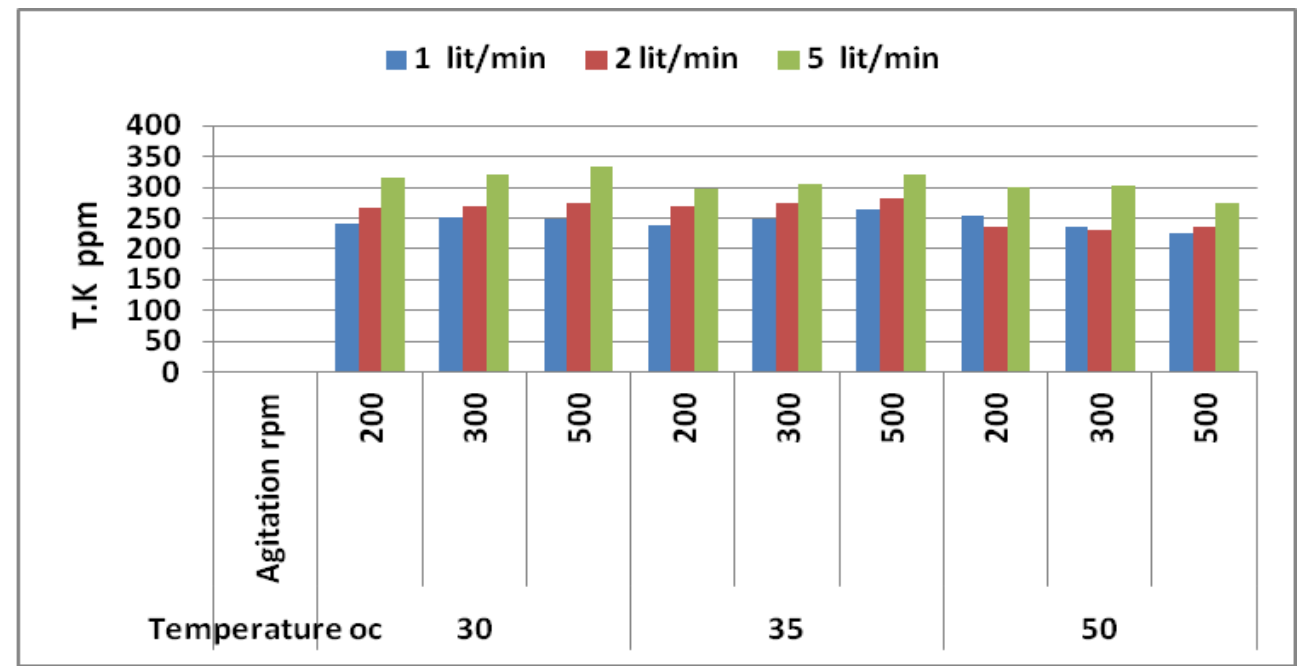

Figure (10): The effect of fermentation temperature, agitation speed and Ventilation rate on the total potassium Biofert.

\section{Microbial changes:}

Figure (11) shows the microbial load of tested human pathogens (E.coli, Salmonella sp and Shigella sp) during biofert process as affected by ventilation, agitation and temperature. Results clearly depicted that a sharp decrease in the counts of all tested human pathogens with the increase of ventilation up to $5 \mathrm{~L} / \mathrm{min}$. The reduction percentages of all tested were ranged from 88.18 to $99.82 \%$. It means that the ventilation levels had a deleterious effect on the proliferation of human pathogens. On the other hand the increase of dissolved oxygen led to increase the biological activity of saprophytic microorganisms and consequently increase their metabolites especially antagonistic agents and antibiotics. The two levels of temperatures being $30 \mathrm{oC}$ and $35 \mathrm{oC}$ did not show a distinct difference where as $50{ }^{\circ} \mathrm{C}$ completely destroyed all human pathogens during biofert process. Agitation also exhibited the same trend 
of both tested temperature. This result is in line with Brinton et. al., 2001 who observed that the disappearance of pathogens could be explained on the basis that when a beneficial microbe fills an ecological niche that would otherwise be exploited by a pathogen. For example, a beneficial organism may out-compete a pathogen for energy, nutrients, or "living space," thereby decreasing the survival of the pathogen.

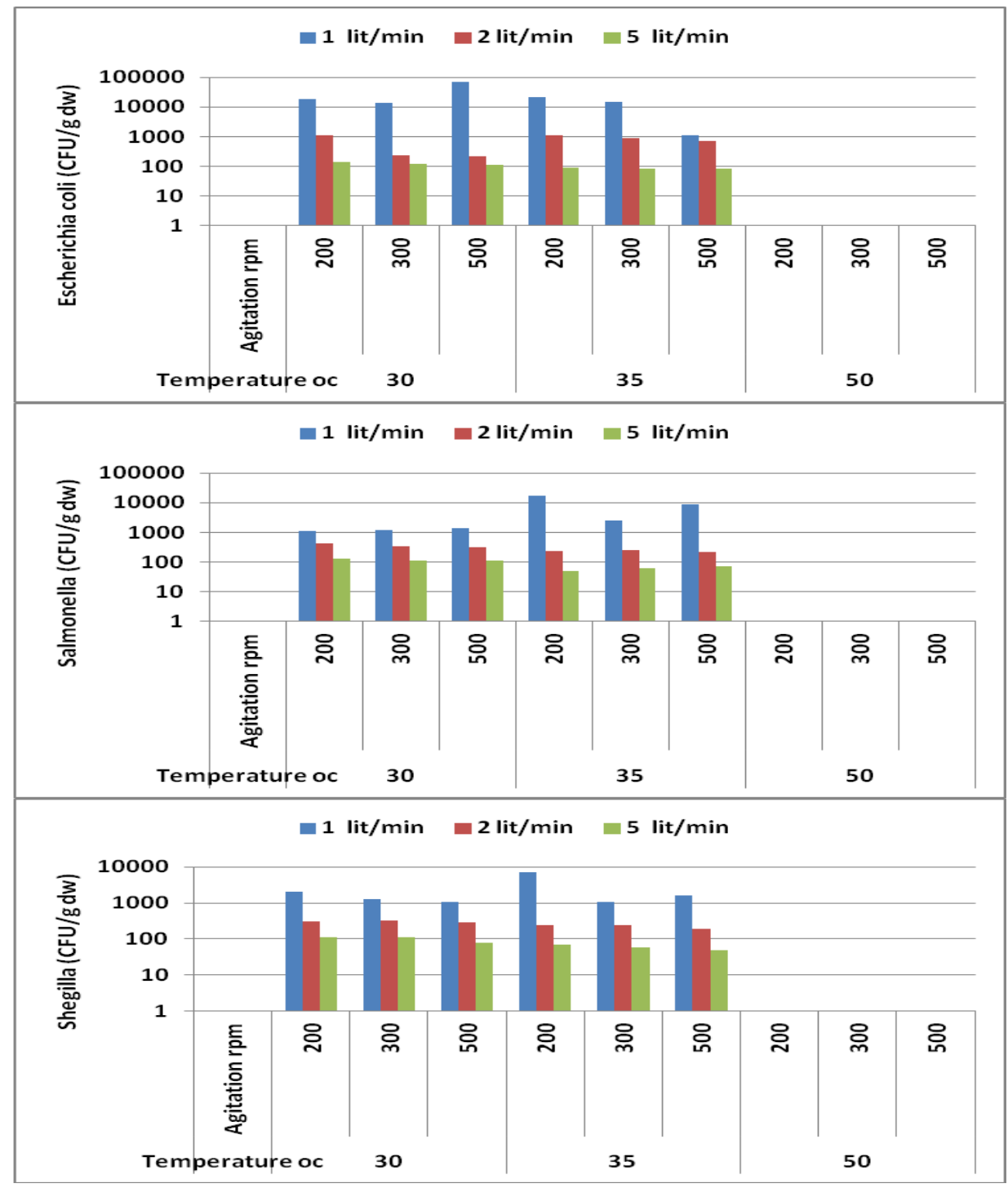

Figure (11 a,b,c): The effect of fermentation temperature, agitation speed and Ventilation rate on Total account of Pathogenic ( CFU/gDW) on biofert 


\section{SUMMARY AND CONCLUSION}

This study was carried out to investigate the most important factors affecting the biofert production such as temperature, agitation speed, and aeration rate to obtain the proper factors for optimum production of the nutrient solution. The most important results could be summarized as follows:-

- The results indicated that the lowest value of bulk density was $946.63 \mathrm{~kg} / \mathrm{m}^{3}$ at temperature of $50^{\circ} \mathrm{C}, 300 \mathrm{rpm}$ agitation speed and 5 liter/ $\mathrm{min}$, ventilation rate while the highest value $\left(983.17 \mathrm{~kg} / \mathrm{m}^{3}\right)$ obtained at temperature $30^{\circ} \mathrm{C}, 500 \mathrm{rpm}$ agitation speed and 1 liter/ min ventilation rate.

- The lowest moisture content was $79.87 \%$ at temperature of $30^{\circ} \mathrm{C}$, agitation speed of 200rpm and ventilation rate of 1 liter/ min while the highest value was $83.19 \%$ at temperature of $50^{\circ} \mathrm{C}$, agitation of 500rpm and ventilation rate of 5 liter/ $\mathrm{min}$.

- The electrical conductivity increased from $11.6 \mathrm{ds} \mathrm{m}-1$ at the start of fermentation to $35.07 \mathrm{ds} \mathrm{m}-1$ at the end of fermentation period depending on the treatments under study. The $\mathrm{pH}$ decreased from 8.13 at the start of fermentation to 6.77 at the end of fermentation period.

- The total solid of the biofert decreased from $21.2 \%$ at the start of fermentation to $16.81 \%$ at the end of fermentation period, where the lowest value was $16.81 \%$ at temperature of $50^{\circ} \mathrm{C}$, agitation speed of 500rpm and ventilation rate of 5 liter/ min and the highest value $(20.13 \%)$ recorded at temperature of $30^{\circ} \mathrm{C}$, agitation speed of 200rpm and ventilation rate of 1 liter/ min.

- The lowest $\mathrm{TN} \%$ was $0.41 \%$ at $50^{\circ} \mathrm{C}$ fermentation temperature, agitation speed of 500rpm and ventilation rate of 1 liter/ min while, the highest value $(1.18 \%)$ obtained at temperature of $35^{\circ} \mathrm{C}$, agitation speed of 300rpm and ventilation rate of $5 \mathrm{liter} / \mathrm{min}$.

- The O.M \% decreased from $34.2 \%$ at the start of fermentation to $10.97 \%$ at the end of fermentation period. The lowest value of O.M $\%$ was $10.97 \%$ at temperature of $50^{\circ} \mathrm{C}$, agitation speed of $500 \mathrm{rpm}$ 
and ventilation rate of 5 liter/ $\mathrm{min}$ while the highest value was $16.63 \%$ at temperature of $30^{\circ} \mathrm{C}$, agitation speed of $200 \mathrm{rpm}$ and ventilation rate of 1 liter/ min.

- The total phosphorus and potassium increased by increasing the fermentation temperature from 120 to $322 \mathrm{ppm}$, and from 150 to $334.33 \mathrm{ppm}$, respectively by the end of fermentation period.

- Regarding the microbial changes, all treatments showed disappearance of pathogenic microorganisms at temperature of $50^{\circ} \mathrm{C}$, at all agitation speeds and ventilation rates.

\section{REFERENCES}

Angenent, L.T., Karim, K., Al-Dahhan, M.H., Wrenn, B.A., Domiguez-Espinosa, R.,2004. Production of bioenergy and biochemicals from industrial and agricultural wastewater. Trends Biotechnol. 22, 477-485.

Audu, T.O.K.; F.A. Aisien and E.O. Eyawo (2003). Biogas from Municipal Solid Waste, NJEM, 4(1):26-30.

Behera, S.K., Park, J.M., Kim, K.H., Park, H., 2010. Methane production from food waste leachate in laboratory-scale simulated landfill. Waste Manage. 30, 1502-1508.

Brinton, W. F.; Evans, M. L.; Brinton, R. B. and Droffner, M. L.(2001). A Standardized Dewar Test for Evaluation of Compost Self-Heating. BioCycle Report 1-16.

Chapman, H.D. and F.P.Pratt(1961). Methods of analysis for soil, plants and water.Univ. of California,Div.of Agric. Sci.

Charles, W., Walker, L., Cord-Ruwisch, R., 2009. Effect of preaeration and inoculum on the start-up of batch thermophilic anaerobic digestion of municipal solid waste. Bioresour. Technol. $100,2329-2335$ 
Clark, E. R., J. P. Harman and J. R. M. Forster (1985). Production of metabolic and waste products by intensively farmed rainbow trout, Salmo gairdneri Richaedson. Journal of Fish Biology, 27: 381-393.

De Baere, L., 2006. Will anaerobic digestion of solid waste survive in the future.

Elvira, C.; Sampedro, L.; Benitez, E. and Nogales, R. (1998). Vermicomposting of sludge from paper mill and dairy industries with Eisenia Andrei: A pilot- scale study. Bioresource Technol., 63:205-211.

Jackson, M.L. (1973). Soil Chemical Analysis, Prentice-Hall Englewood cliffs, New Jersey.

Jackson, M.L. (1973). Soil Chemical Analysis, Prentice-Hall Englewood cliffs, New Jersey.

Jeong, E., Kim, H., Nam, J., Shin, H., 2010. Enhancement of bioenergy production and effluent quality by integrating optimized acidification with submerged anaerobic membrane bioreactor. Bioresour. Technol. 101, 1873-2976.

Jingura, R.M., Matengaifa, R., 2009. Optimization of biogas production by anaerobic digestion for sustainable energy development in Zimbabwe. Renew. Sust. Energy Rev. 13, 1116-1120.

Kim, J.K., Oh, B.R., Chun, Y.N., Kim, S.W., 2006. Effects of temperature and hydraulic retention time on anaerobic digestion of food waste. J. Biosci. Bioeng. 102, 328-332.

Ogbeide SE, Aisien FA (2000). Biogas from Cassava peelings, Afr. J. Environ. Stud., (1-12): 42-47.

Olsen, S.R.; Cole, C.V.; Watanabe, F.S. and Dean, L.A. (1954).Estimation of available phosphorus in soils by extraction with sodium bicarbonate. US Dept. Agric., Circular No. 939, 19 p. 
Park, C., Lee, C., Kim, S., Chen, Y., Chase, H.A., 2005. Upgrading of anaerobic digestion by incorporating two different hydrolysis processes. J. Biosci. Bioeng. 100, 164-167.

Park, C., Lee, C., Kim, S., Chen, Y., Chase, H.A., 2005. Upgrading of anaerobic digestion by incorporating two different hydrolysis processes. J. Biosci. Bioeng. 100, 164-167.

Raviv,M., Chen, Y. and Inbar, Y.(1987).Peat and Peat substitutes as growth media for container grown plants-A review. In : The rol of organic matter in modern agriculture.(Chen,Y.and Avnimelech,Y.(Ed)) Martinus Nijhoff, the Hegue, 257-87.

Richards,L. A.(Ed.)(1954). Diagnosis and Improvement of Saline and Alkali Soil. U.S.Dept. Agric., Handbook, No. 60 Gov. print off.

Richards,L.A. (1954). Diagnosis and improvement of saline and alkaline soil. Dept. Agric.,Agric. Handbook No. 60: 17-337. USA.

Singh, M. and Sharma, S. D. (2002). Bioefficacy of azafenidin for weed management in citrus. Weed Sci. Soc. Amer. Annual Meeting. February 10-13, 2002. Reno, NV, Abstr. 21, p. 7.

Steyer, J.P., Bouvier, J.C., Conte, T., Gras, P., Sousbie, P., 2002. Evaluation of a four year experience with a fully instrumented anaerobic digestion process. Water Sci.Technol. 45, 495-502.

Torres, M.L., de Llorens, M.C.E., 2008. Effect of alkaline pretreatment on anaerobic digestion of solid wastes. Waste Manage. 28, 22292234

Ward, A.J., Hobbs, P.J., Holliman, P.J., Jones, D.L., 2008. Optimization of the anaerobic digestion of agricultural resources. Bioresour. Technol. 99, 7928-7940.Water Sci. Technol. 53, 187194. 


\section{الملخص العربي}

تأثير بعض العوامل الهندسية على خصائص السماد الحيوى

$$
\begin{aligned}
& \text { رامى محمد حمودة"، عادل حامد بهنساوى***، سمير أحمد على***، } \\
& \text { زكريا عبد الرحمن الحداد** و الشحات محمد رمضان**** }
\end{aligned}
$$

أجريت التجربة لدر اسة تأثير بعض العوامل الهندسية على إنتاج السماد الحيوى من تخمر سبلة

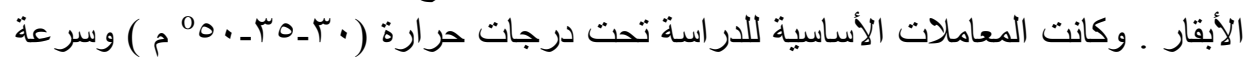

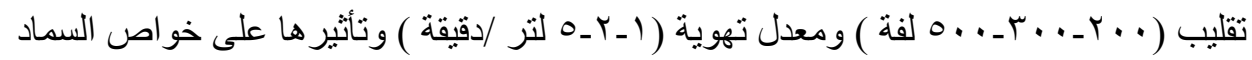

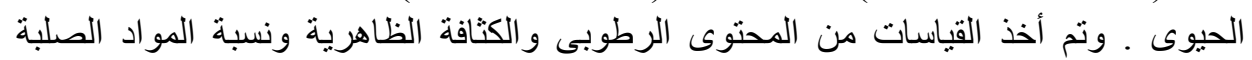

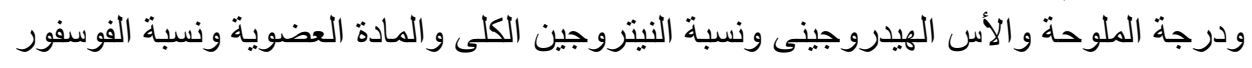

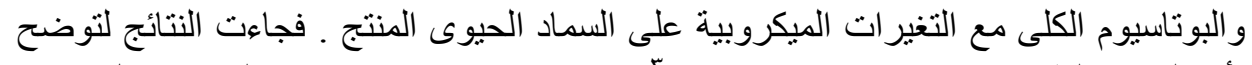

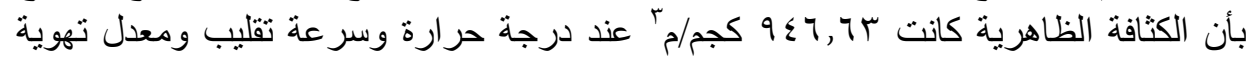

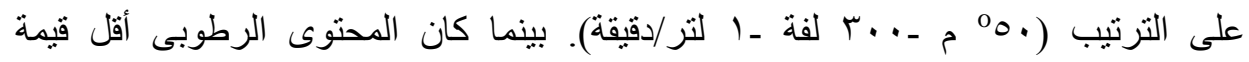
\% \% ع , ^V

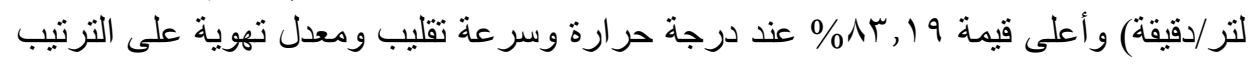

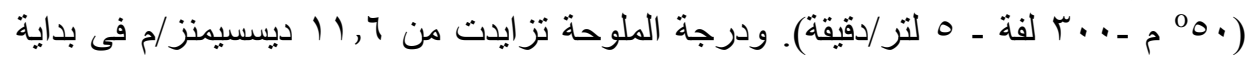

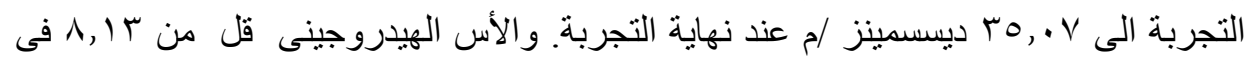

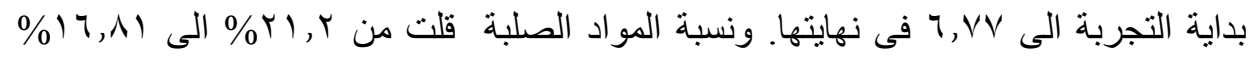

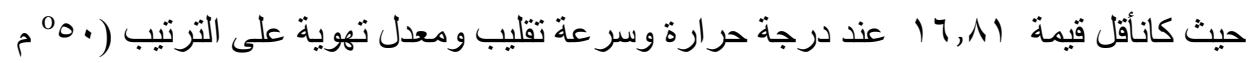

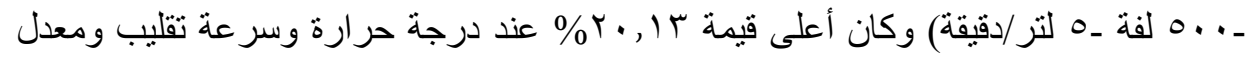

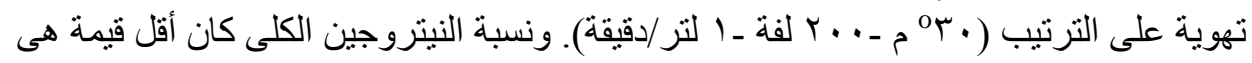

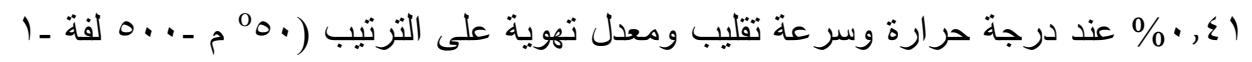

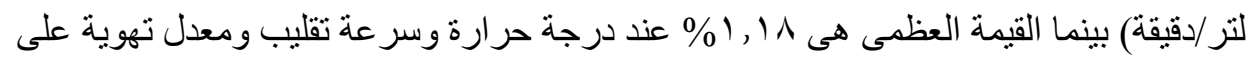

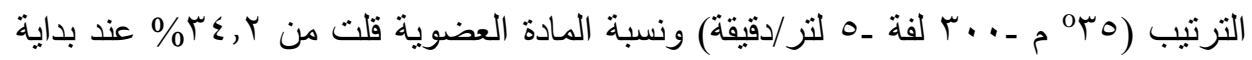

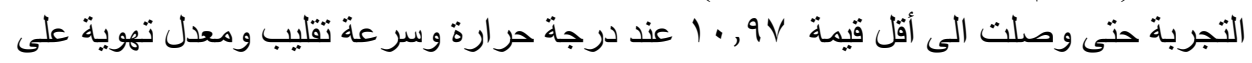

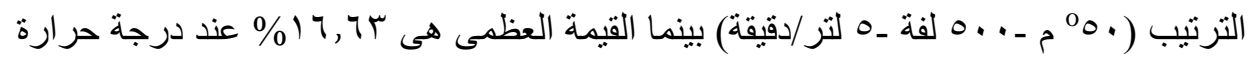

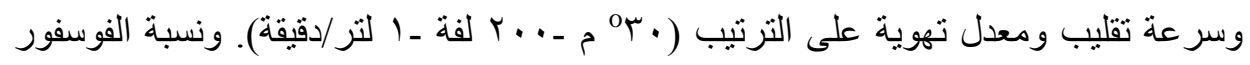

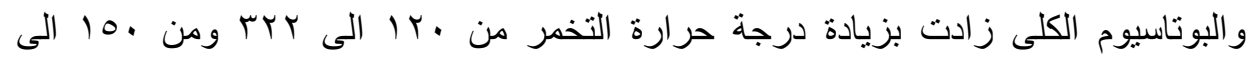

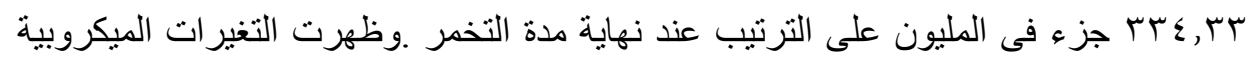
لجميع المعاملات وأتضح عدم ظهور الميكروبات المرضية عند كل المعاملات الخاصة بدرجة لماته

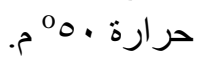

\footnotetext{
* طالب در اسات عليا ـ قسم الهندسة الزراعية ـ كلية الزراعة بمشتهر - جامعة بنها.

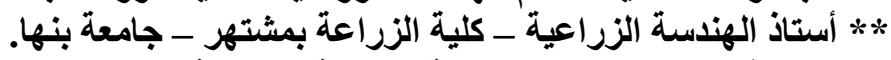

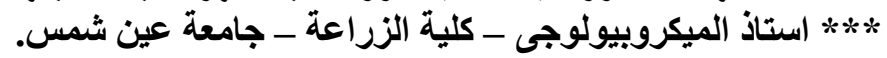

